\title{
IDENTIFIKASI FASAD ARSITEKTUR TROPIS PADA GEDUNG-GEDUNG PERKANTORAN JAKARTA (STUDI KASUS PADA KORIDOR DUKUH ATAS-SEMANGGI)
}

\author{
Anwari Dananjaya, Alpha Febela Priyatmono, Samsudin \\ Program Studi Teknik Arsitektur, Fakultas Teknik, Universitas Muhammadiyah Surakarta \\ Jl. A. Yani Tromol Pos 1 Pabelan Kartasura Sukoharjo 57102 Telp 0271-717417 \\ E-mail: febela2006@yahoo.co.id
}

\begin{abstract}
ABSTRAK
Penelitian ini dilatar belakangi kondisi Jalan Jenderal Sudirman di Jakarta yang merupakan jalan protokol dan menjadi salah satu landmark ibukota Republik Indonesia. Jalan Jenderal Sudirman adalah jalan protokol yang terkenal banyak menjadi tempat berdirinya gedung-gedung tinggi, sehingga dapat dikatakan menjadi brandimage jika ingin mengetahui perkembangan konsep dan desain gedung tinggi di Indonesia.Tampilan bentuk gedung tinggi di kawasan ini yang sangat variatif menjadi salah satu alasan kenapa topik ini diangkat menjadi topik penelitian. Tujuan penelitian ini adalah untuk mengidentifikasi elemen-elemen arsitektur tropis pada fasad gedunggedung perkantoran jalan Jenderal Sudirman yang rata-rata memiliki tipikal fasad minimalis , studi kasus pada Koridor Dukuh Atas-Semanggi. Metoda Penelitian yang dipakai dalam penelitian ini adalah dengan metoda kualitatif diskriptif yang dalam pelaksanaannya diawali dengan kegiatan survei lapangan atau pengamatan/ observasi dan didukung dengan studi literatur. Sedangkan obyek penelitian adalah fasad pada gedung-gedung kantor sepanjang jalan Jendral Sudirman terbatas pada koridor Dukuh Atas-Semanggi dengan menjabarkan fasad secara umum, dan fasad secara khusus dengan mengambil satu unit gedung dengan kriteria tertentu sebagai sample penelitian. Hasil penelitian menyimpulkan bahwa tampilan fasad gedunggedung cenderung memakai fasad minimalis tanpa ada variasi kecuali sedikit untuk menyesuaikan dengan konsep fasad minimalis yang berada di wilayah iklim tropis.
\end{abstract}

Kata Kunci: fasad, arsitektur tropis, gedung minimalis

\section{PENDAHULUAN}

Jalan Jenderal Sudirman di Jakarta adalah sebuah jalan protokol yang menjadi salah satu landmark ibukota Republik Indonesia. Ruas jalan Jenderal Sudirman memanjang sesuai arah mata angin dari Utara ke Selatan, di sebelah Utara ditandai oleh sebuah landmark, lahan air mancur dengan monumen patung (sculpture) bertema tugu selamat datang, yang terkenal dengan sebutan Air Mancur Bundaran Hotel Indonesia. Jalan Jenderal Sudirman adalah jalan protokol yang terkenal banyak menjadi tempat berdirinya gedung-gedung tinggi, sehingga dapat dikatakan menjadi brandimage jika ingin mengetahui perkembangan konsep dan desain gedung tinggi di Indonesia. Akan tetapi fasad gedung-gedung tingginya secara formal didominasi oleh fasad minimalis yang justru tidak mencerminkan konsep arsitektur Indonesia yang berada di wilayah tropis.

Pada jalan protokol ini terdapat sebuah koridor bernama Dukuh Atas-Semanggi yang dijadikan obyek penelitian, yang memiliki batas-batas fisik berupa Sungai Banjir Kanal Barat di utara Dukuh Atas dan SimpangSusun Semanggi yang menghubungkan Jalan Jenderal Sudirman dengan Flyover Jalan Gatot Subroto, yang melintang ke arah TimurBarat di atas jalan Jendral Sudirman.

Dukuh Atas adalah nama sebuah wilayah eks perkampungan pada koridor Jalan Jenderal Sudirman yang berada di luar administratif mandiri yang dikelilingi oleh gedung-gedung perkantoran seperti hotel Shangri-La,Gedung BNI'46, gedung Artha- 
loka, Wisma Indocement, dan Landmark Center (2 tower)

Semanggi adalah nama sebuah simpang-susun (interchange) yang berada di Jakarta Selatan. Simpang-Susun ini mempertemukan dua jalan raya utama di Kota Jakarta, yaitu Jalan Jenderal Sudirman dan Jalan Jenderal Gatot Subroto , Dengan kondisi seperti inilah simpang-susun Semanggi dijadikan sebagai Point of Interest oleh gedung Balai Sarbini (Semanggi Square) dan dijadikan landmark alamat-alamat Places of Interest seperti Jakarta Convention Center (JCC) Selain itu di kawasan semanggi terdapat bangunan-bangunan gedung lain yang mengelilinginya seperti Gedung Menara BRI (2 tower), Wisma GKBI, Hotel Hilton, Apartemen Hilton, dan Gedung Polda Metro Jaya

\section{Rumusan Permasalahan}

Jalan Jenderal Sudirman termasuk koridor Dukuh Atas - Semanggi yang memiliki banyak gedung-gedung tinggi sebagai brandimage konsep Arsitektur Bangunan Tinggi di Indonesia sebagian besar menampilkan fasad minimalis yang tidak sesuai dengan kontekstual Indonesia sebagai bagian dari wilayah beriklim tropis. Arsitektur tropis adalah konsep yang masih dapat diaplikasikan pada gedung/ bangunan tinggi seperti pada desain dan fasad Gedung Wisma Dharmala Sakti serta usaha pemasangan kanopi tambahan pada beberapa unit gedung untuk beradaptasi dengan iklim tropis setempat"

\section{Pertanyaan Penelitian}

Jika fasad dari gedung-gedung yang berada di jalan Jendral Sudirman koridor Dukuh Atas - Semanggi cenderung secara umum mengambil tema dan fasad minimalis, sejauh manakah penerapannya dalam mengadaptasi arsitektur lokal yang cenderung bertema Arsitektur Tropis?

\section{METODE PENELITIAN}

\section{Teknik Pengumpulan Data}

Metode penelitian dilakukan dengan model kuyalitatif - diskriptif. Dalam penelitian ini pengumpulan data dilakukan dengan survey observasi serta literatur .Survey dilaksanakan dengan pengamatan sederhana yang dibantu dengan alat bantu berupa kamera (pocket-digital) untuk mengamati obyek-obyek bangunan gedung yang akan diangkat sebagai topik utama penelitian, sementara Observasi dilakukan dengan pengamatan lebih lanjut untuk memfokuskan permasalahan penelitian, seperti menentukan luasan wilayah survey dan wawancara kepada subyek yang berada di wilayah obyek penelitian.

Studi literatur dilakukan dengan pencarian sumber-sumber pustaka yang berasal dari buku-buku studi ilmiah, arsip koran dan majalah. Artikel-artikel ilmiah itu juga terdapat selain di buku ada pula di artikel seminar, dan dipublikasikan secara online bersama forum-forum diskusi arsitektur di internet. Selanjutnya pola pikir metode penelitian dapat digambarkan melalui bagan sebagai berikut :

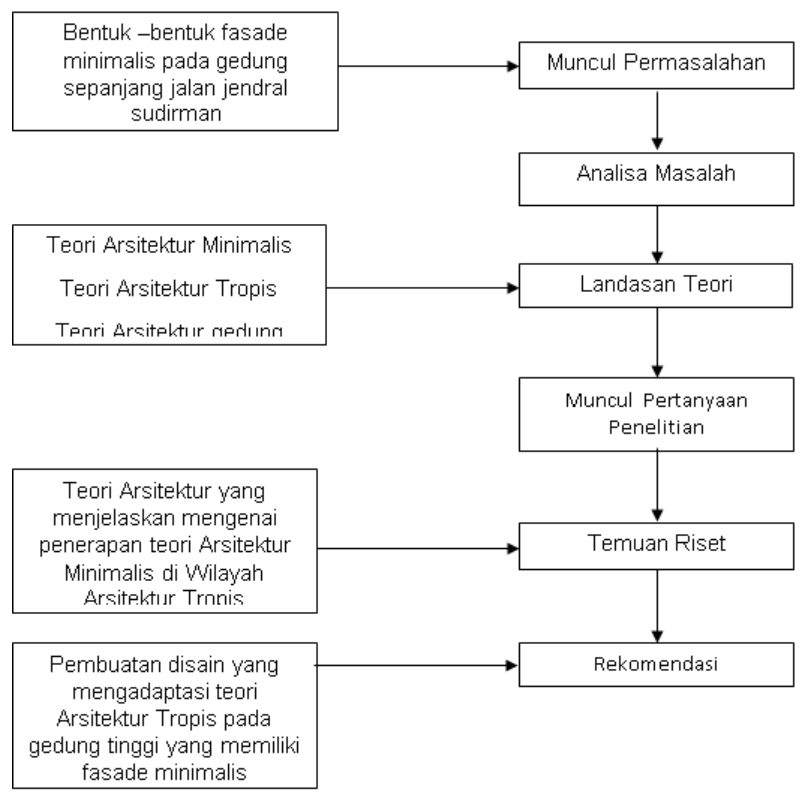

Gambar 1. Pola pikir penelitian Sumber: Peneliti, 2010

\section{KAJIAN PUSTAKA Arsitektur Tropis}

Secara harafiah, Arsitektur tropis adalah sebuah produk pemikiran dan budaya yang tumbuh dan berkembang di wilayah iklim tropis. Secara alamiah ia mengalami perkembangan dan pertumbuhan baik secara fisik maupun non fisik seiring dengan pertambahan dan kemajuan waktu, pemikiran, dan teknologi.

Adapun kemudian muncul elemenelemen yang berhasil menjadi pokok-pokok elemen arsitektur tropis akan terus diuji dan 
mengalami formologi, seperti modifikasi atap, ruang teras, ventilasi, tanpa mengurangi fungsi utama dari arsitektur tropis untuk mengatasi masalah iklim tropis.

Corsini (1997) mengatakan bahwa Ikllim mikro di sekitar bangunan perlu dikendalikan dengan memanfaatkan tanaman hijau yang berdaun gelap dan lebat. Sangat ideal jika $30 \%$ - $70 \%$ volume ruang lahan bangunan terisi tanaman hijau dan 30\% - 70\% luasan permukkaan tanah tidak ditutupi material keras. Kehalusan permukaan dan warna bahan bangunan sangat menentukan iklim mikro di sekitar bangunan, warna cerah dan permukaan licin adalah pemantul sinar matahari yang baik dan menaikkan suhu sekitar. Warna gelap dan permukaan kasar akan membantu meredam dan menyerap sinar dan panas matahari.

Menurut Khadiyanto (1997) dalam Teori Sajian Desain Arsitektur Tropis \& Ramah Lingkungan (2008), alangkah baiknya bila tiap kawasan itu memiliki Master Plan Drainage dan menyelesaikan permasalahan mereka sendiri-sendiri. Daerah yang tinggi menyelesaikan masalahnya di atas pula, bukan membuangnya begitu saja ke daerah bawah sehingga yang bawah pun tidak akan terlampau berat memikul beban dirinya ditambah beban kiriman daerah lain.

Menurut Corsini (1997) dalam Koneksitas Arsitektur dengan ingkungannya (2008) , konsep dasar dari menifestasi ide tentang arsitektur yang kembali ke alam adalah hakikat dari ekologi manusia atau ekologi sosial. Manusia sebagai penghuni bangunan dan kota adalah relasi dari lingkungan fisik alam dan lingkungan sosialnya. Merupakan arsitektur yang mempergunakan bahan alam secara konsekuen. Kebutuhan oksigen, makanan alami, air bersih, pengaturan suhu dan kelembaban seluruhnya disediakan dalam bangunan yang integral dengan alamnya. Suhu udara diatur oleh lebatnya tanaman dan jarak letak bangunan. Elemen bangunan yang rusak mudah diganti dengan bangunan sekitarnya. Arsitektur ramah lingkungan merupakan dunia yang alami dalam skala mikro. Bangunan, tanaman, udara, tanah, air, binatang, dan jasad renik serta manusia dijadikan satuan ekosistem yang erat dalam skala bangunan.

\section{Arsitektur Minimalis}

Minimalis dapat diartikan dengan penyederhanaan bentuk, kesederhanaan massa, ataupun mempermudah ciri khas non ornamental. Salahsatu rujukan para arsitek dalam mengambil nilai-nilai minimalisme yang berakar dari budaya tradisional yang elegan adalah ketika membicarakan teknik arsitektur minimalis jepang. YB. Mangunwijaya (1995) dalam bukunya "Wastu Citra membicarakan kesederhanaan gaya jepang yang memurnikan gaya maupun bentuk yang memunculkan kesan minimalis. Istilah minimalis sebagai satu konsep atau gaya dalam rancangan rumah tinggal tengah marak digunakan di masyarakat kita, khususnya sejak sekitar tahun 1990-an. Sekalipun konsep dasar minimalis ini telah muncul akibat revolusi industri dan kebangkitan paham modernisme dalam sejarah arsitektur dan berkembang sejak tahun 1920-an setelah kelahiran gaya arsitektur International Style yang mengusung tema functionalism (fungsinal), clarity (kejelasan) dan simplicity (kesederhanaan). Satu gerakan penolakan terhadap peniruan dan pengulangan bentukbentuk lama serta penggunaan ornamentasi masa klasik yang dipandang berlebihan, non struktural dan sekadar tambahan yang sebenarnya tidak memberi makna apa-apa dalam arsitektur. Di lain pihak menyuarakan kenyataan kemajuan teknologi dalam proses rancangan, konstruksi dan struktur bangunan yang memberi kemudahan, akurasi dan efisiensi.

\section{Arsitektur Gedung Tinggi Indonesia}

Arsitektur gedung tinggi di Indonesia
tidak bisa dilepaskan dari sejarah pembangunan struktur Hotel Indonesia di sisi bundaran $\mathrm{HI}$ yang menjadi proyek satu paket ketika diadakan Asian games 1962 dan diresmikan langsung oleh Presiden Soekarno. Momen lain dari sejarah gedung tinggi di Indonesia adalah ketika gedung Wisma BNI 46 dibangun. 


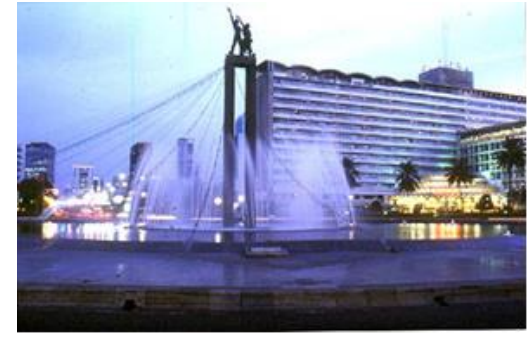

Gambar 2. Hotel Indonesia (sekarang Kempinski Group). Sumber: Survey, 2009

Dengan jumlah lantai struktur 46 tingkat diluar lantai service dan basement maka gedung ini menjadi gedung tertinggi sekaligus menjadi ikon gedung tinggi modern di Indonesia yang mengaplikasikan elemen-elemen arsitektur modern kontemporer.

Arsitektur gedung tinggi di Indonesia sebagaimana dengan negara-negara berkembang lainnya yang baru merdeka pada pertengahan abad 20, dimulai pada periode arsitektur "International Style". Bangunan tinggi pertama di Indonesia adalah "Hotel Indonesia", di Jakarta (1959) karya arsitek Amerika Abel Sorensen dan Wendy Sorensen yang penggunaannya diresmikan tanggal 5 Agustus 1962, serta "Wisma Nusantara", di Jakarta, karya arsitek Jepang dengan ketinggian 30 lantai dengan menerapkan teknologi tahan gempa.

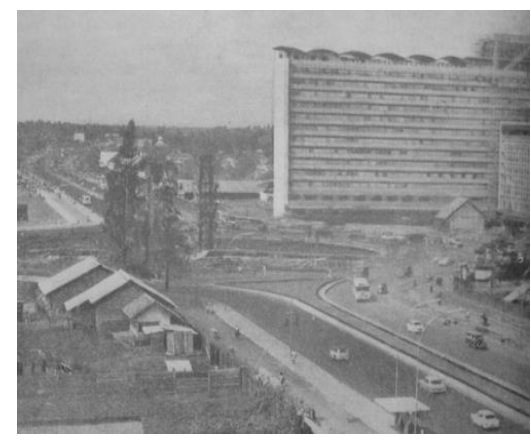

Gambar 3. Hotel Indonesia, 1962 Sumber: google.com

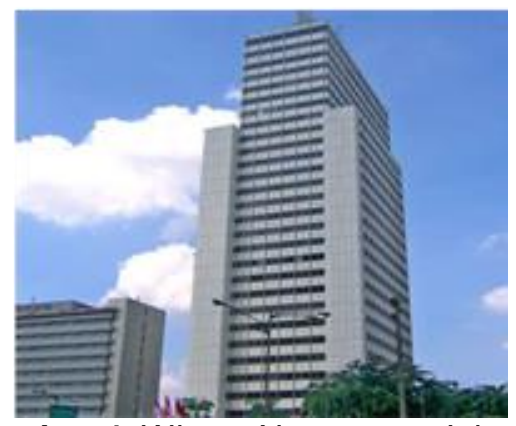

Gambar 4. Wisma Nusantara, Jakarta Sumber: Survey, 2009
Sejak Jalan Jendral Sudirman dibangun pada awal 1960-an terjadi perkembangan gedung-gedung tinggi pada koridor Jalan Jendral Sudirman dan Jl. M.H. Thamrin pada awal 1970-an. Begitu juga dengan J. H.R. Rasuna Said yang dibangun pada tahun 1970-an. Sebagaimana dengan negaranegara berkembang lainnya, pertumbuhan gedung-gedung tinggi yang mendominasi wajah kota dilaksanakan tanpa kendali sehingga bangunan yang hadir kurang memiliki pemahaman terhadap kondisi sosial, budaya dan ekonomi masyarakatnya.

\section{HASIL DAN PEMBAHASAN}

Berdasarakan pengamatan lapangan ditemukan data sebagai berikut:

Tabel 1. Data Hasil Amatan

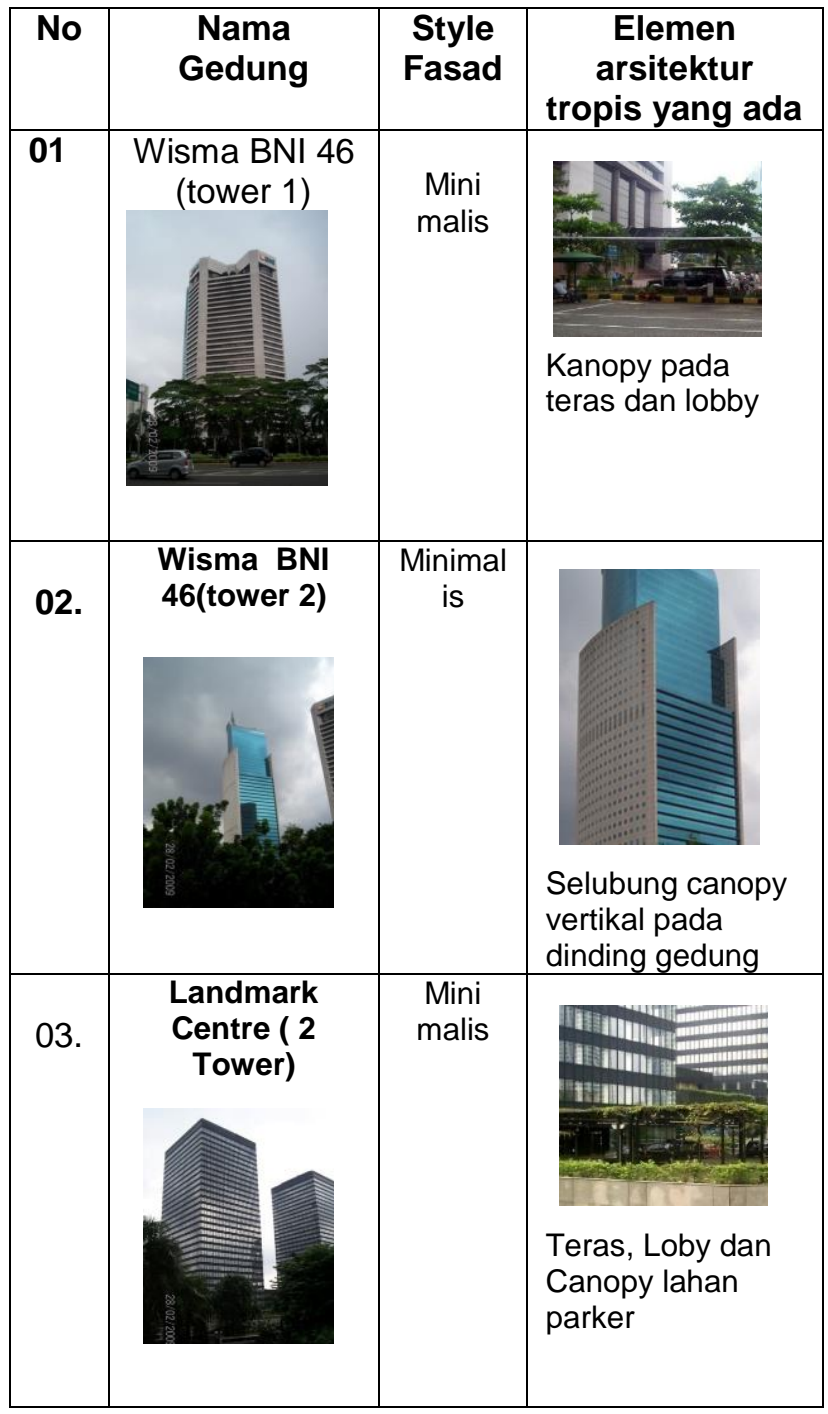




\begin{tabular}{|c|c|c|c|}
\hline No & $\begin{array}{l}\text { Nama } \\
\text { Gedung }\end{array}$ & $\begin{array}{l}\text { Style } \\
\text { Fasad }\end{array}$ & $\begin{array}{c}\text { Elemen } \\
\text { arsitektur } \\
\text { tropis yang ada }\end{array}$ \\
\hline 04 & $\begin{array}{c}\text { Wisma } \\
\text { Indocement }\end{array}$ & $\begin{array}{l}\text { Mini } \\
\text { malis }\end{array}$ & $\begin{array}{c}\text { Canopy pada tera } \\
\text { dan Loby }\end{array}$ \\
\hline 05 & $\begin{array}{c}\text { Wisma } \\
\text { Arthaloka }\end{array}$ & $\begin{array}{l}\text { Mini } \\
\text { malis }\end{array}$ & $\begin{array}{c}\text { Sirip Kanopi } \\
\text { horisontal pada } \\
\text { dinding, teras dam } \\
\text { loby }\end{array}$ \\
\hline 06 & $\begin{array}{c}\text { Wisma } \\
\text { Bumiputera }\end{array}$ & $\begin{array}{l}\text { Mini } \\
\text { malis }\end{array}$ & $\begin{array}{c}\text { Kanopi pada teras } \\
\text { dan loby }\end{array}$ \\
\hline 07 & $\begin{array}{l}\text { Indofood } \\
\text { Tower }\end{array}$ & $\begin{array}{l}\text { Mini } \\
\text { malis }\end{array}$ & $\begin{array}{c}\text { Kanopy pada } \\
\text { teras dan loby }\end{array}$ \\
\hline 08 & Marein Tower & $\begin{array}{l}\text { Mini } \\
\text { malis }\end{array}$ & Kanopy pada \\
\hline
\end{tabular}

\begin{tabular}{|c|c|c|c|}
\hline 09 & $\begin{array}{c}\text { Wisma Kyoiei } \\
\text { Prince }\end{array}$ & $\begin{array}{l}\text { Mini } \\
\text { malis }\end{array}$ & $\begin{array}{l}\text { Kanopy pada } \\
\text { teras dan loby }\end{array}$ \\
\hline 10 & $\sqrt{1}$ & $\begin{array}{l}\text { Mini } \\
\text { malis }\end{array}$ & $\begin{array}{l}\text { Sirip dinding } \\
\text { balkon dan kanopi } \\
\text { teras pada loby }\end{array}$ \\
\hline 11 & Plaza Permata & $\begin{array}{l}\text { Mini } \\
\text { malis }\end{array}$ & $\begin{array}{c}\text { Kanopi pada teras } \\
\text { loby }\end{array}$ \\
\hline 12 & 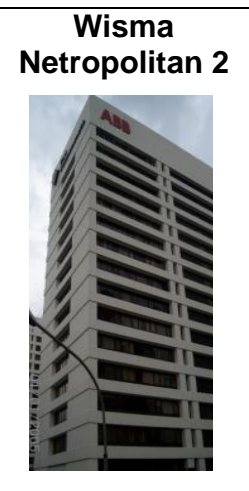 & $\begin{array}{l}\text { Mini } \\
\text { malis }\end{array}$ & $\begin{array}{l}\text { Sirip dinding } \\
\text { balkon dan kanopi } \\
\text { pada teras loby }\end{array}$ \\
\hline 13 & $\begin{array}{c}\text { Wisma } \\
\text { Dharmala Sakti }\end{array}$ & $\begin{array}{l}\text { Mini } \\
\text { malis }\end{array}$ & $\begin{array}{l}\text { Sirp kanopi } \\
\text { massaif, balkon } \\
\text { dan teras pada } \\
\text { loby }\end{array}$ \\
\hline
\end{tabular}




\begin{tabular}{|c|c|c|c|}
\hline No & $\begin{array}{l}\text { Nama } \\
\text { Gedung }\end{array}$ & $\begin{array}{l}\text { Style } \\
\text { fasad }\end{array}$ & $\begin{array}{c}\text { Elemen } \\
\text { arsitektur } \\
\text { tropis yang ada }\end{array}$ \\
\hline 14 & $\begin{array}{c}\text { Plaza } \\
\text { Sampurna } \\
\text { Strategic }\end{array}$ & $\begin{array}{l}\text { Mini } \\
\text { malis }\end{array}$ & $\begin{array}{l}\text { Kanopi pada teras } \\
\text { loby }\end{array}$ \\
\hline 15 & Mild Plaza & $\begin{array}{l}\text { Mini } \\
\text { malis }\end{array}$ & Kanopi pada teras \\
\hline 16 & BRI Tower 1 & $\begin{array}{l}\text { Mini } \\
\text { malis }\end{array}$ & $\begin{array}{l}\text { Kanopi pada teras } \\
\text { loby }\end{array}$ \\
\hline 17 & BRI Tower 2 & $\begin{array}{l}\text { Mini } \\
\text { malis }\end{array}$ & $\begin{array}{l}\text { Kanopi pada teras } \\
\text { loby }\end{array}$ \\
\hline 18 & Plaza Sentral & $\begin{array}{l}\text { Mini } \\
\text { malis }\end{array}$ & $\begin{array}{l}\text { Kanopi pada teras } \\
\text { loby }\end{array}$ \\
\hline
\end{tabular}

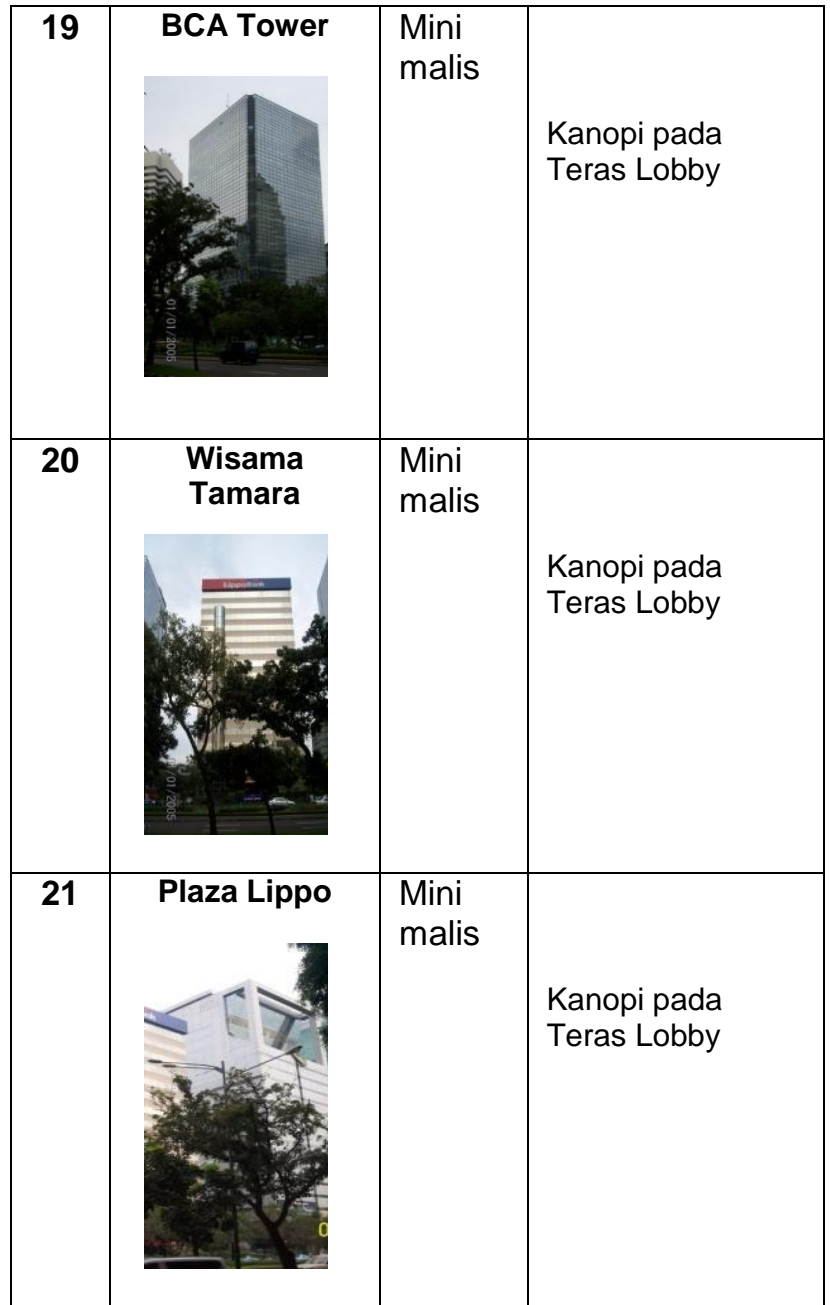

\section{Temuan}

Dari tabel di atas dapat diketahui beberapa karakter fasad secara tipikal yang memiliki karakteristik:

\section{Fasad Dinding Rata/ Transparan}
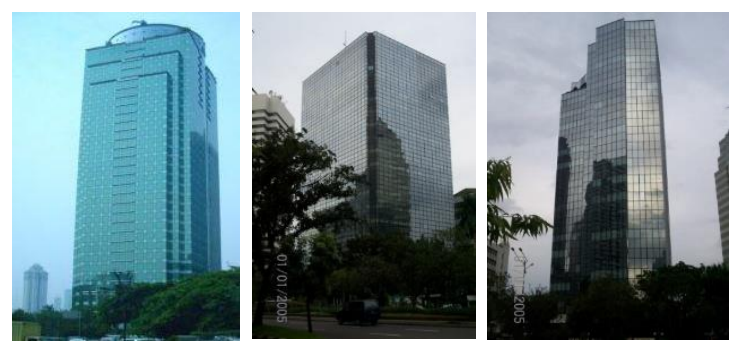

Gambar 5. Fasade Ekterior kaca transparan gedung BRI, BCA. Sudirman Plaza dan

Prodential

Sumber: Survey, 2009

Adalah fasad dengan karakter minimalis paling kuat berupa dinding gedung rata tanpa ada penambahan elemen arsitektur tambahan 
seperti kanopi sebagai adaptasi iklim tropis yang cenderung bercurah hujan tinggi. Pada contoh gedung pusat BCA, Sudirman Plaza/ Prudential, dll. Kebanyakan bermaterial kaca, seratkaca (fiberglass), ataupun dinding solid yang diberi lapisan pelindung weathershield baik berupa pelapis cat emulsi maupun material tahan-cuaca seperti keramik. Hal ini tentu berdampak langsung pada:

- Tingginya biaya pemeliharaan (maintenance) untuk perawatan dinding yang sering terkena air hujan

- Tingginya ongkos operasional gedung yang harus dikeluarkan sebagai konsekuensi pemakaian pengkondisian hawa (AC) karena interaksi dinding dengan pancaran sinar matahari langsung dan dinding yang tidak membantu menyalurkan angin untuk pengkondisian hawa dalam ruangan

\section{Fasad Sirip Balkon Horisontal}
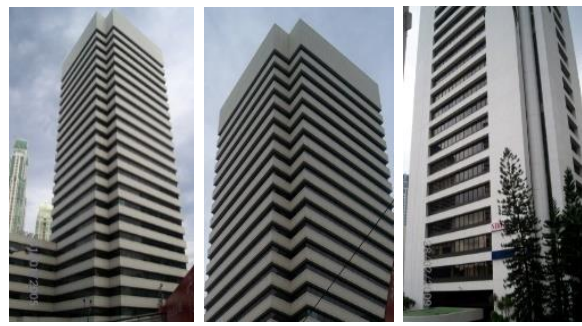

Gambar 6. Sirif massif pada gedung Chese Plaza dan Wisma Indocement Sumber: Survey 2009

Adalah fasad minimalis yang dalam satu segmen lantai memiliki dinding kaca yang dibingkai oleh dinding beton, dimana dinding bingkai beton ini memiliki tepian menonjol; oversteak, tersusun seperti sirip-sirip balkon yang tidak sama-rata dengan dinding kaca dan memberikan dampak layaknya kanopi balkon yang melindungi dinding kaca. Seperti pada contoh gedung Chase Plaza, fasad ini terasa lebih adaptif dengan kondisi iklim tropis dan diharapkan mampu mengurangi pengaruh kontak langsung dengan air hujan dan pancaran sinar matahari sehingga:

- Mengurangi, meskipun sedikit, biaya dari pemeliharaan (maintenance) dinding kaca

- Mengurangi kuat pancaran sinar matahari langsung ke dalam ruangan

\section{Fasad Dinding Selubung Vertikal}
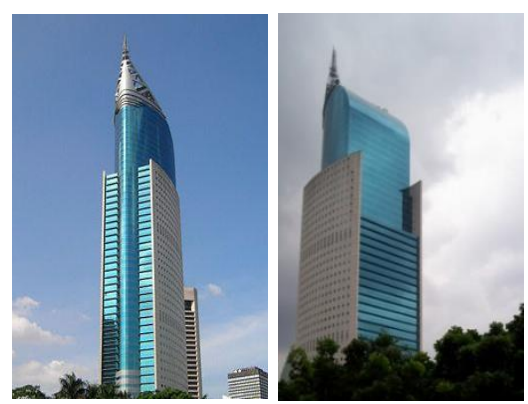

Gambar 7. Selubung kanopi gedung BNI46 Tower II

Sumber: Survey 2009

Adalah fasad minimalis yang memiliki dinding kaca yang diberi selubung (kanopi) vertikal seperti pada gedung Wisma BNI 46 tower II. Selubung ini memberikan dampak untuk mereduksi kontak langsung dinding kaca dengan air hujan dan pancaran sinar matahari langsung layaknya sebuah kanopi.

Dengan bentuknya yang ergonomis terhadap bentuk bangunan secara tidak langsung memperkuat karakternya sebagai gedung dengan fasad minimalis, bahkan modern-kontemporer jika dilihat dari komponen precast alumunium yang menyusunnya. Karena memiliki selubung kanopi maka ia memiliki keuntungan:

- Mengurangi panas yang timbul jika dinding terkena sinar matahari langsung

- Mengurangi dampak dari resiko tingginya biaya pemeliharaan (maintenance) jika terkena air hujan secara langsung

- Memiliki kesempatan guna mengatur penghawaan alami jika pada dinding utama dibalik selubung kanopi diberi sistem ventilasi

\section{Fasad Sirip Kanopi semipermanen}

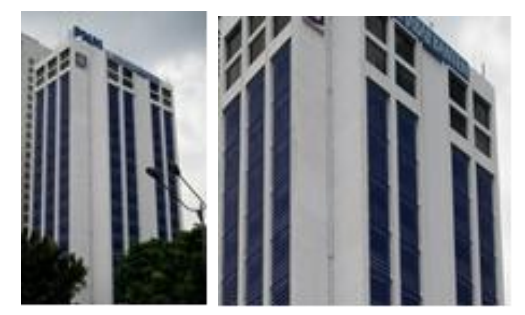

Gambar 8. Sirip-sirip semipermanen Wisma Arthaloka

Sumber: Survey, 2009 
Adalah fasad gedung minimalis yang memiliki dinding utama rata, akan tetapi pada perkembangannya diberi penambahan kanopi semi-permanen. Fasad ini diterapkan pada gedung Wisma Arthaloka, mirip seperti siripsirip ventilasi yang disusun horisontal pada satu bingkai logam/ besi dan dipasang persegmen dari batas antar lantai gedung. Kanopi seperti ini juga memberikan fungsi proteksi yang sama pada dinding bangunan dari pengaruh cuaca tropis, curah hujan serta pancaran sinar matahari langsung

\section{Fasad Dinding Kanopi Masif}
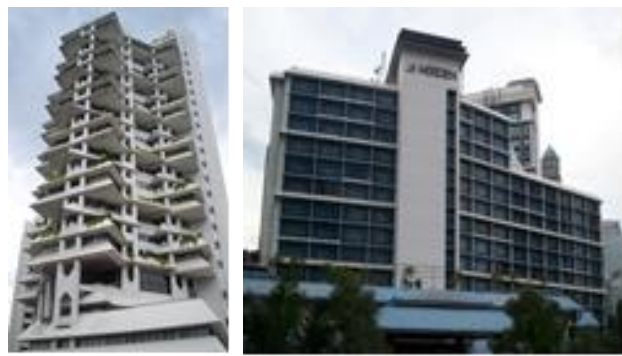

Gambar 9. Kanopi pada Gedung Wisma Dharmala Sakti Sumber: Survey, 2009.

Adalah fasad gedung minimalis yang dikatakan berhasil mengadaptasi kondisi iklim tropis dengan penerapan dinding ber-kanopi penuh seperti pada gedung Wisma Dharmala Sakti, dan jika bisa dimasukkan sebagai contoh, pembanding setara adalah gedung Hotel 'Le Meridien' yang terletak tepat di seberang sebelah utara Wisma Dharmala Sakti

Gedung yang memakai fasad seperti ini menerapkan secara penuh fungsi kanopi sebagai pelindung bangunan dari kontak langsung dengan air hujan dan pancaran sinar matahari. Ruangan yang berada di bawah kanopi-kanopi didesain menjadi balkon, terrace yang berfungsi sebagai ruang peredam kecepatan angin kencang untuk dipecah dan dimasukkan melalui ventilasi sebagai penghawaan alami ruang-ruang serta dapat dimanfaatkan untuk penghematan biaya penghawaan buatan (AC).

Berikut ini solusi adaptasi tropis pada bangunan fasad minimalis:

\section{Kanopi pada Teras dan Lobby}

Salah satu elemen arsitektur tropis yang diambil dan dipakai dalam fasad arsitektur minimalis gedung-gedung tinggi di jalan
Jendral Sudirman koridor Dukuh Atas Semanggi adalah pemakaian Kanopi praktis.

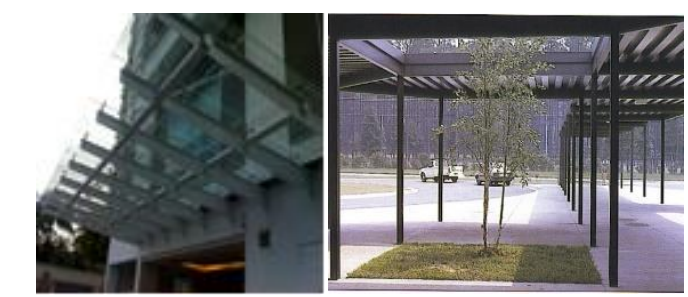

Gambar 10. Contoh Kanopi style modernkontemporer Sumber: Survey, 2009.

Pada awalnya fungsi kanopi yang diletakkan pada entrance gedung adalah untuk memberi perlindungan user dari hujan, panas, dan angin kencang yang biasa terjadi di iklim luar. Kemudian detail bangunan dari kanopi dikembangkan selain untuk mewadahi fungsi umum yang tersebut di atas, kanopi juga sebagai elemen pembentuk citra dari gedung terkait dimana setiap dari periode pembangunan gedung akan menyesuaiakan teknologi terkini pada masa pembangunannya.

Beberapa tipe Kanopi yang umum dipakai pada obyek penelitian ini memiliki beberapa karakteristik:

- Kanopi massif dari elemen struktur beton bertulang yang sebagian besar memakai finishing keramik seperti kanopi pada gedung Indocement Tower, Wisma Arthaloka, Chase Plaza, Mid Plaza, Wisma Metropolitan 1 \& 2, Mayapada Tower, dan gedung pusat BRI Tower-2

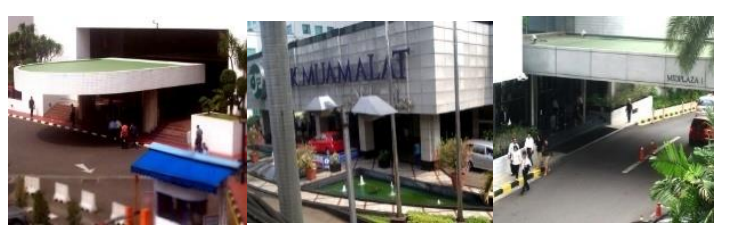

Gambar 11. Kanopi massif struktur beton bertulang

Sumber: Survey, 2009.

- Kanopi struktur massif struktur beton bertulang dengan elemen precast polycarbonate yang diletakkan sebagai skylight pada lobby gedung. Kanopi tipe ini diaplikasikan pada teras gedung BNI Tower-2, Wisma Bumi Putera, Wisma Kyoei Prince, Plaza Permata, Plaza Sentral, dan gedung pusat BRI Tower-1 

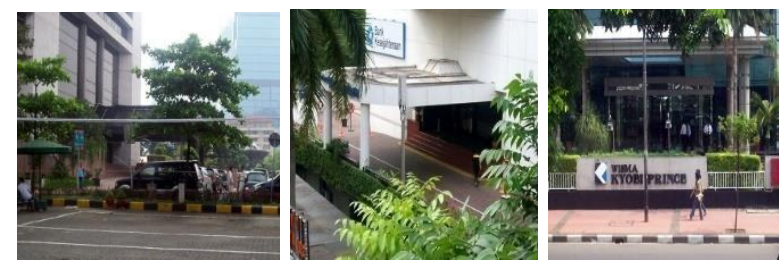

Gambar 12. Kanopi struktur beton atap polycarbonate; skylight Sumber: Survey, 2009.

- Kanopi precast dari elemen struktur komposit ringan seperti fiberglass, rangka alumunium, dan bentang kabel baja penahan momen. Model ini diaplikasikan pada teras dan lobby gedung Marein Tower, Indofood Center, Plaza Prudential, dan gedung Sampoerna Strategic.
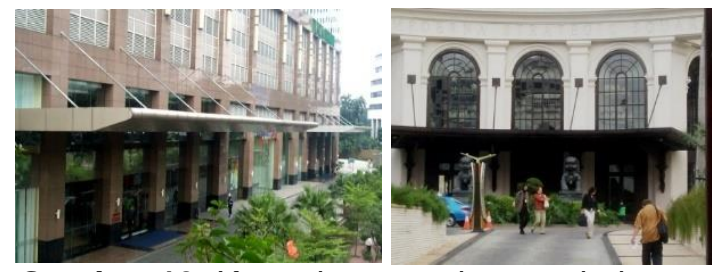

Gambar 13. Kanopi precast komposit ringan, kabel baja

Sumber: Survey, 2009.

- Kanopi rangka besi yang dijadikan semacam para-para; struktur yang mewadahi vegetasi/ tanaman sebagai elemen peneduh. Tipe ini diaplikasikan pada lingkungan gedung Landmark Center (2 tower). Kanopi ini memiliki ciri khusus yaitu pemakaian vegetasi/ tanaman pada skala yang lebih luas secara kuantitatif untuk menciptakan pembayangan dan kanopi. Pemakaian vegetasi/ tanaman ini sendiri merupakan konsep yang selaras dengan konsep arsitektur tropis yang memakai tanaman sebagai salah-satu elemennya
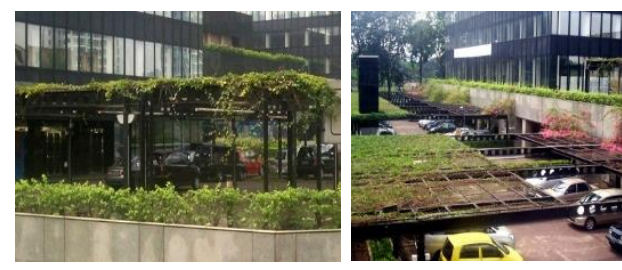

Gambar 14. Kanopi para-para vegetasi pada lobby dan area parkir Sumber: Survei 2009.

Fasad Arsitektur tropis pada Gedunggedung Minimalis Perkantoran yang menjadi tipikal di wilayah Jalan Jenderal Sudirman, Jakarta pada umumnya memiliki ciri khas yang hampir sama dengan fasad bangunanbangunan gedung yang ada di lingkungan iklim tropis. Beberapa hal telah dijadikan pertimbangan dan masukan dalam Arsitek mendesain dan mengadaptasi iklim tropis ke dalam desain fasad gedung, seperti teras/ lobby, beranda/ balkon, serta roofgarden, selain modifikasi yang terjadi kemudian seperti penambahan kanopi praktis. Beberapa temuan pada sub-bab pembahasan sebelumnya dapat kita jadikan sebagai acuan dalam melakukan analisa lanjut dan masuk dalam sub-bab pembahasan ini.

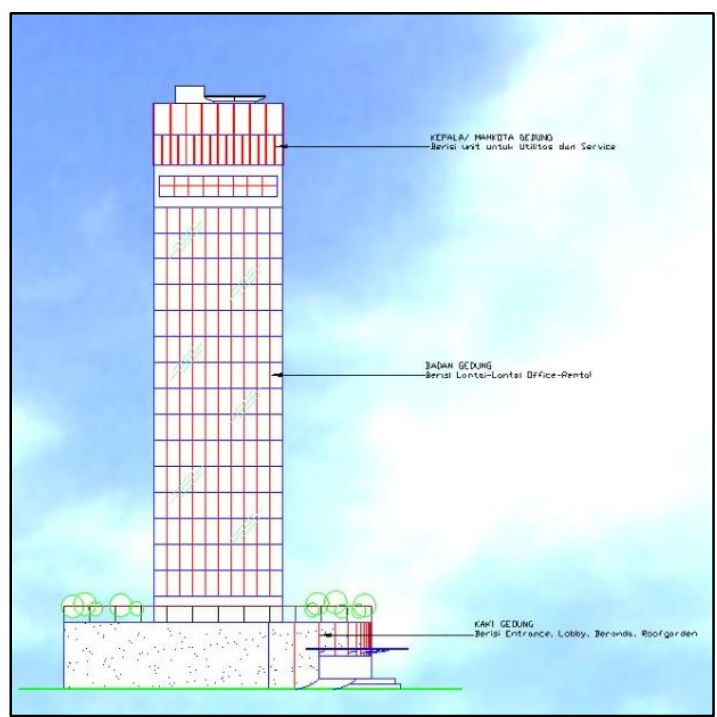

Gambar 15. Tipikal Fasad Tropis pada gedung-gedung Minimalis di Jalan Jendral Sudirman Jakarta

Jalan Jenderal Sudirman, Jakarta dapat kita analogikan dengan satu macam contoh yang akan ditelaah dan dijadikan pedoman umum dalam memahami anatomi gedung yang mengaplikasikan fasad Arsitektur Tropis

\section{Kepala/ Topping Gedung}

Pada level yang terdapat pada bagian teratas dari gedung terdapat unit-unit utilitas, servis dan maintenance. $\mathrm{Di}$ sini terletak mesin-mesin utama Lift, HVAC, WaterTorn, alat-alat maintenance gedung seperti kereta gondola maupun robot, Helipad, dan yang terkini adalah landasan untuk berbagai perangkat komunikasi nirkabel seperti antenna radio dan telepon seluler. 


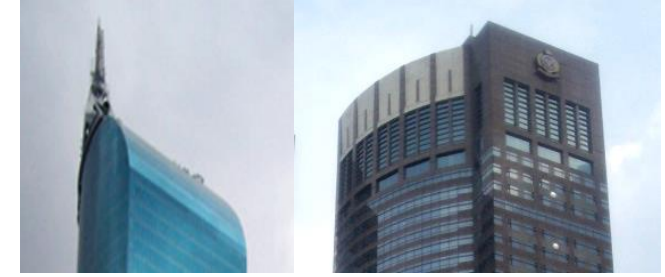

Gambar 16. Fasad Topping Gedung tipikal minimalis di jalan Jendral Sudirman Sumber : Survei 2009

Pada level ini biasanya elemen-elemen arsitektur tropis sangat minim dan bisa dikatakan tidak ada kecuali untuk ornamental.

\section{Badan Gedung}

Pada bagian tengah atau menjadi pusat orientasi kegiatan gedung ini terdapat lantai-lantai (storey) yang disesuaikan dengan fungsinya. Seperti pada obyek-obyek penelitian ini yang berorientasi pada gedung perkantoran sehingga memiliki sifat untuk memfasilitasi kegiatan kantor seperti Bisnis dan Jasa.

Elemen-elemen arsitektur tropis dapat diaplikasikan pada level ini karena tampilan fasad yang terbentuk dapat dijadikan brand atau model. Selain itu aplikasi elemenelemen arsitektur tropis pada level badan gedung yang membentuk satu cirri khas atau style tertentu akan menjadikan karakter fasad gedung terkait menjadi khas dan menguatkan citra sebuah gedung seperti sebuah landmark.
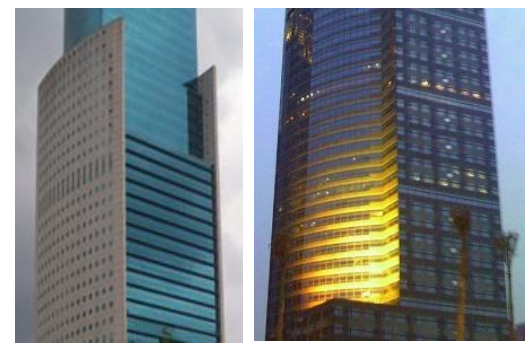

Gambar 17. Fasad Badan Gedung tipikal minimalis di jalan Jendral Sudirman Sumber: Survey, 2009

\section{Kaki Gedung}

Pada gedung-gedung fasad minimalis yang mengaplikasikan elemen-elemen arsitektur tropis, pada level kaki gedung inilah banyak ditampilkan elemen seperti kanopi dan overhang yang diaplikasikan pada entrance gedung, kanopi pada parapara dan balkon, dan juga kanopi pada lahan parkir,

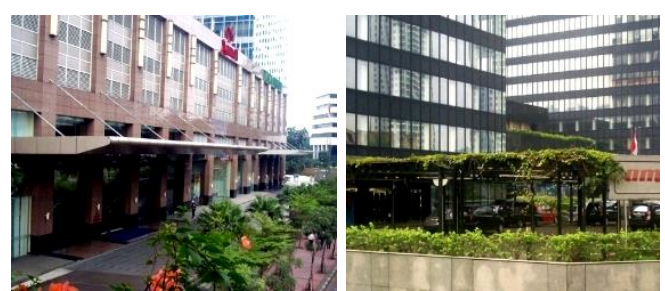

Gambar 18. Tampilan Kanopi dan Para-para pada level Kaki Gedung

Sumber: Survey, 2009.

Banyaknya aplikasi elemen-elemen arsitektur tropis pada level ini tidak terlepas dari parameter sudut pandang mata manusia (eye-catching), estetika dan teknis momen yang lebih kecil dibanding level diatasnya.

\section{KESIMPULAN DAN SARAN}

Dari Penelitian ini dapat kita ambil beberapa kesimpulan yang memberikan sebuah gambaran umum akan permasalahan yang terjadi pada tampilan fasad minimalis yang diterapkan pada gedung-gedung sepanjang jalan Jenderal Sudirman koridor DukuhAtas-Semanggi

Kesimpulan yang dapat kita ambil salahsatunya adalah bahwa fasad gedunggedung tinggi memiliki pengaruh terhadap ruang dalam (interior). Pengaturan dan pemilihan konsep Arsitektur Tropis diharapkan akan memberikan dampak yang sama yang dihasilkan oleh bangunan tropis skala rumah yang mengatasi permasalahan angin, curah hujan tinggi, panas dan kelembaban

- Pada gedung Wisma Dharmala Sakti pada lantai pengelola (kira-kira lantai 2 \&3) menggunakan penghawaan dan pencahayaan alami luar ruang yang disesuaikan dengan konsep fasad gedung yang memang mengambil konsep Arsitektur tropis murni. Mereka berusaha memanfaatkan kondisi iklim kecil yang terjadi akibat dari pengaturan fasad yang menciptakan Teras, Balkon pada badan gedung. Teras dan Balkon secara konseptual adalah ruang perantara antara angin luar yang menuju ke dalam.

- Pada beberapa unit gedung seperti Mid Plaza, Indocement Center, Wisma Bumi Putera, Wisma Dharmala Sakti menggunakan kanopi Lobby dengan struktur beton bertulang dan finishing keramik dinding, begitu pula keramik 
dinding diaplikasikan pada badan hingga topping gedung. Hal ini membuktikan bahwa elemen keramik yang merupakan satu elemen wilayah tropis dapat digunakan untuk mengatasi iklim tropis terutama panas yang akan masuk ke dinding beton dan curajh hujan lebat yang akan menimbulkan korosi pada dinding beton gedung.

\section{Saran}

Beberapa saran yang dapat penulis berikan terutama dengan konsep dan teori arsitektur untuk gedung-gdung tinggi, terutama di wilayah Indonesia yang beriklim tropis adalah:
- Dengan iklim tropis yang memiliki ciri khas tersendiri seperti curah hujan yang tinggi dan panas secara bergantian dalam satu tahun, maka pemikiran mengenai usaha mengatasi permasalahan iklim tropis tetap menjadi prioritas utama

- Meskipun penting mengenai pemilihan fasad yang akan ditampilkan, ia tetap mampu menjaga kontekstualitas karya arsitektur dengan lingkungannya, terutama ketika dunia saat ini sedang ramai dan populer membicarakan dampak pemanasanglobal.

\section{DAFTAR PUSTAKA}

Mangunwijaya, Y.B., 1995, Arsitek Muda Indonesia sebuah refleksi, buku jurnal AMI, Jakarta

Mangunwijaya, Dipl.Ing.Y.B. 1995, Wastu Citra, penerbit Gramedia Majalah, Jakarta

Sukendar, Sukendro, 2006, Minimalis dalam Minimalisme, Materi Seminar, IAI Jakarta

Susanto, C., 2006, Desain Bangunan Minimalis Jepang, Artikel lepas teori minimalis jepang;

Daryanto, Ir., Peran Selubung Bangunan Tropis dalam Mewujudkan Kota Hemat Energi, sebuah Thesis S-2 dosen Ubinus-Jakarta; tidak dipublikasikan

Liu, Anthony, 2006, Arsitek dan Arsitektur dalam Minimalis Kekinian, Pengantar dalam Seminar Arsitektur Minimalis dalam Minimalisme, IAI Jakarta

Anonymous, 2008, Teori Sajian Desain Arsitektur Tropis dan Ramah Lingkungan, topik diskusi dalam www.arsiteka.com

Adhistana, Ir., 2008, Gaya Arsitektur Kontemporer Tropis, artikel lepas http://adhisthana.tripod.com/artikel/gaya1

Anonymous, 2000, Minimalisme Dalam Arsitektur, Artikel Harian Kompas minggu, 5 Maret 2000

http://forum.wgaul.com/archive/thread/t-18655-Arsitektur-Gedung-Tinggi

http://c.sutanto.or.id/desain/bangunan-minimalis-1 